\title{
THE ROLE OF SCIENTIFIC AND RESEARCH WORK IN THE PROCESS OF FORMATION OF PROFESSIONAL COMPETENCE OF FUTURE SPECIALISTS OF FIRE SAFETY OF HIGHER EDUCATIONAL ESTABLISHMENTS OF SES OF UKRAINE
}

\section{НАУКОВО-ДОСЛІДНИЦЬКА РОБОТА У ПРОЦЕСІ ФОРМУВАННЯ ПРОФЕСІЙНОЇ КОМПЕТЕНТНОСТІ МАЙБУТНІХ ФАХІВЦІВ 3 ПОЖЕЖНОЇ БЕЗПЕКИ ЗВО ДСНС УКРАЇНИ}

Ihor NOZHKO, Candidate of Pedagogical sciences

Ігор НОЖКО, кандидат педагогічних наук nogko1991@gmail.com https://orcid.org/0000-0003-1554-0088

Mykola PELYPENKO, Candidate of Pedagogical sciences nicolaStayer@gmail.com https://orcid.org/0000-0003-1961-5008

\section{Denys LAHNO,} researcher of department of organization of scientific activity

\section{Денис ЛАГНО,} науковий співробітник відділу організації наукової діяльності lagno0407@gmail.com https://orcid.org/0000-0002-3663-6858

Cherkasy institute of fire safety named after Chornobyl Heroes National university of civil protection of Ukraine

8, Onoprienka Str., Cherkasy, 18034 Черкаський інститут пожежної безпеки імені Героїв Чорнобиля Національного університету цивільного захисту України $\triangle$ Вул. Онопрієнка, 8 м. Черкаси, 18034

Original manuscript received: November 11, 2021

Revised manuscript accepted: December 15, 2021

\section{ABSTRACT}

The authors proved that such personality qualities as readiness for selfeducation, creativity are particularly important for the specialist of fire safety. It is highlighted that the research work become increasingly important and are transformed into one of the main components of training future specialist of civil protection in terms of higher education. The role of research work for future specialists of civil protection in the process of their professional competence are analyzed.

Reasoned scientific position on the need for a rational combination of traditional and innovative forms and methods of both auditorium and non-auditorium activities are grounded; the complexity level of research aims; compliance with the ratio between auditorium and non-auditorium activities; providing individual and differentiated approaches; matching student's interests and opportunities with the curriculum requirements or the aims and objectives of research work; ensuring the adequate numbers of reference and methodological literature, guidance on the 
separate tasks implementation; usage of digital libraries (learn using electronic textbook, e-lectures, abstracts, usage of electronic educational and methodical complex); control over the implementation of research tasks.

Principles of preparing of future specialists of fire safety to research activity: consistency, continuity, comprehensiveness, integration, predictability, scientific and innovational principles are defined.

Research work of future specialists of fire safety are examined on the basis of characteristics and prospects of higher education due to the competence approach, which are aimed at the development of new scientific knowledge, theoretical systematization of objective knowledge about the nature of the profession.

Perspectives of further scientific studies are in researching the development of criteria, levels and indicators for assessing the research quality.

Key words: professional competence; specialist of fire safety; research activity.

Постановка проблеми. Підвищення ролі людського фактора в різних сферах життя суспільства зумовлює посилення вимог до рівня професіоналізму випускників закладів вищої освіти ДСНС України, здатних вирішувати складні завдання, прогнозувати та моделювати результати власної професійної діяльності тощо. Найбільш затребуваними стають не просто висококваліфіковані фахівці, а й ті, які здатні самостійно орієнтуватися в інформаційному просторі, порівнювати, аналізувати, узагальнювати, знаходити найкращі варіанти розв'язання професійних задач, а отже, здійснювати дослідження в конкретних галузях знань. Сучасні фахівці з пожежної безпеки повинні володіти всіма властивостями, необхідними для самостійного формулювання, аналізу та вирішення професійних проблем, тобто володіти дослідницькими навичками.

Для фахівця з пожежної безпеки ЗВО ДСНС України особливого значення набувають такі якості особистості, як готовність до самоосвіти, креативність, здатність здійснювати пошукову діяльність, поглиблювати знання. Особливим критерієм, який характеризує рівень фахової підготовки майбутнього фахівця з пожежної безпеки, виступає його профресійна компетентність.

У зв'язку з цим науково-дослідницька робота набуває все більшого значення і трансформується в один із основних компонентів професійної підготовки майбутнього фрахівця з пожежної безпеки в умовах освітнього процесу ЗВО ДСНС України.

Аналіз останніх досліджень і публікацій. Концептуальні положення та науково-методичні засади підготовки фахівців з пожежної безпеки служби цивільного захисту висвітлюють О. Бикова, М. Варій, Н. Вовчаста, В. Доманський, М. Коваль та ін. Психолого-педагогічні засади управління навчально-виховним процесом розкривають А. Алексюк, В. Андрущенко, С. Вітвицька, С. Гончаренко, Р. Гуревич, В. Маслов, Н. Ничкало та ін.

Різні аспекти проблеми компетентності розглядають С. Гончаренко, І. Драч, Т. Ткаченко, А. Хрипунова, М. Чобітько, О. Шапран, В. Ягупов та ін.

Питання ролі науково-дослідницької діяльності як компонента професійної підготовки майбутніх фахівців знайшли своє відображення в 
роботах С. Архипової, О. Бикової, О. Біди, О. Дягилевої, А. Кузьмінського, Г. Лохонової, С. Сисоєвої, М. Солдатенка, О. Смірнової та ін.

У них обґрунтовується значимість цього виду діяльності для розвитку інтелектуальних якостей особистості, науково-дослідницька робота розглядається як засіб формування наукового світогляду, спеціальних знань і науково-дослідницьких умінь і навичок, розвитку самостійності та активності, обґрунтовуються форми та методи ії організації у ЗВО дСНС України.

Важливість проблеми формування науково-дослідницьких умінь фахівців з пожежної безпеки підкріплює аналіз профресіограм фахівців різних напрямків, у які включені вміння формулювати і вирішувати проблеми, системного аналізу, абстрагування, формалізації тощо.

У контексті нашого дослідження ми робимо акцент на першорядному значенні науково-дослідницької роботи майбутніх фрахівців з пожежної безпеки служби цивільного захисту як важливого елемента їхньої профресійної компетентності.

Мета статті - проаналізувати роль науково-дослідницької роботи майбутніх фахівців з пожежної безпеки ЗВО ДСНС України в процесі формування їхньої професійної компетентності.

Виклад основного матеріалу. Професійна компетентність майбутнього фахівця з пожежної безпеки служби цивільного захисту набуває особливої актуальності, оскільки неможливо забезпечити рівень безпеки та своєчасної допомоги населенню без наявності означеної характеристики тих, хто безпосередньо впроваджує в життя країни цей вид соціального замовлення [5; 6]. Аналіз доробку науковців засвідчує цілком аргументовану позицію щодо обґрунтування ролі науково-дослідницької роботи в контексті професійної компетентності фрахівців з пожежної безпеки.

Особливо цінною для нашого дослідження $€$ наукова позиція І. Драча про те, що «формування компетентності як здатності до співорганізації суб'єктом власних та інших ресурсів для досягнення певної мети передбачає і фрормування ресурсів суб'єкта, які можна поділити на внутрішні (знання, вміння і навички, цінності, мотиви, психологічні особливості) та зовнішні (соціальні, матеріально-технічні), що забезпечують реалізацію внутрішніх ресурсів у різних ситуаціях і обставин життєдіяльності». Основними ознаками компетентнісного підходу в освіті є: поєднання особистісної та діяльнісної орієнтації в освітньому процесі; акцентування уваги на результатах освіти, якими $є$ не лише сума засвоєних знань, умінь і навичок, а й здатність людини діяти в різноманітних проблемних та соціальних ситуаціях. Компетентнісно орієнтована освіта, як наголошує науковець, спрямована на формування здатності або готовності мобілізувати всі свої ресурси (системно організовані знання, уміння та навички, здібності й психічні якості), які необхідні для розв'язання різних проблем [3]. 
Вивчення проблеми формування професійної компетентності засобами науково-дослідницької роботи показало необхідність педагогічного обґрунтування організації цього процесу.

Організація науково-дослідницької роботи розглядається як сукупність цілеспрямованих процесуальних дій суб'єктів (викладачів, студентів тощо) у навчальний та позанавчальний час згідно 3 технологіями, які забезпечують реалізацію особистісно орієнтованої моделі взаємодії 3 метою формування в майбутнього фрахівця необхідних компетенцій [5].

Науково-дослідницька робота фрахівців з пожежної безпеки ЗВО дСНС України здійснюється відповідно до: законів України «Про наукову і науково-технічну діяльність», «Про освіту, «Про вищу освіту»; Положення про вищі навчальні заклади МBC, затвердженого наказом України від 14.02.2008 № 62; розпорядження МВС України «Про визначення базових вищих навчальних закладів МВС України» від 05.06.2008 № 612; пріоритетних напрямів наукових досліджень i науково-технічних розробок ЧІПБ ім. Героїв Чорнобиля НУЦЗ України на 2020-2024 роки, щорічних Планів наукової і науково-технічної діяльності ЧІПБ ім. Героїв Чорнобиля НУЦЗ України, інших загальнодержавних, відомчих планів і програм розвитку вищої освіти та науки, наказів ректора, рішень ректорату та вченої ради НУЦЗ України, начальника ЧІПБ ім. Героїв Чорнобиля НУЦЗ України.

Науково-дослідницька робота сприяє мобілізації творчих сил майбутніх фахівців з пожежної безпеки ЗВО ДСНС України, надає умови для формування самостійних дослідницьких навичок. Тому освітній процес має бути організований таким чином, щоб слухачі могли самостійно оволодіти комплексом знань і вмінь, навчитися керувати собою і обставинами, діяти логічно, знаходити способи самореалізуватися тощо [1].

Вища школа, виконуючи соціальне замовлення суспільства, повинна забезпечити безперервність освіти та самоосвіти майбутніх фрахівців з пожежної безпеки служби цивільного захисту, допомогти оволодіти ефрективними методами самостійної науково-дослідницької діяльності. Вагомою в контексті досліджуваної проблеми є думка професора А. Кузьмінського про те, що сьогодні значно зростає роль ЗВО у навчанні студента самостійно здобувати знання [4].

Принципово важливою для нашого дослідження $€$ наукова позиція О.Біди та О. Савченко, відповідно до якої студент має усвідомлювати себе не лише споживачем, а й розповсюджувачем своєї індивідуальної пізнавальної діяльності. Реалізація цього стане можливою за умови використання групової фрорми організації самостійної роботи [2].

Аналіз досвіду діяльності вищої школи дає змогу виділити такі види науково-дослідницької роботи студентів: підготовку до семінарських занять, аналіз наукової літератури, укладання бібліографії; підготовку повідомлень та рефрератів; написання тез, 
статей, звітів про проходження практики; участь у студентських наукових гуртках і радах наукових товариств, олімпіадах, конференціях, науково-практичних семінарах; розробку проєктів; участь у науководослідній роботі випускової кафедри; вивчення й узагальнення передового досвіду органів внутрішніх справ, підготовку та захист курсових і кваліфікаційних робіт тощо.

Ефективність науково-дослідницької роботи майбутніх фахівців 3 пожежної безпеки ЗВО ДСНС України залежить від:

1) раціонального поєднання традиційних та інноваційних форм i методів організації як аудиторної, так і позааудиторної роботи;

2) рівня складності науково-дослідних завдань;

3) співвідношення між аудиторною та позааудиторною роботою;

4) забезпечення індивідуального та диференційованого підходу;

5) зіставлення інтересів та можливостей курсантів з вимогами навчального плану або цілями та завданнями науково-дослідницької роботи;

6) наявності належної кількості довідкової та науково-методичної літератури, методичних вказівок щодо виконання самостійних завдань;

7) використання можливостей електронних бібліотек (навчання 3 використанням електронного посібника (підручника); електронної лекції, конспекту; електронного навчально-методичного комплексу);

8) рівня контролю за виконанням науково-дослідних завдань.

Наголосимо, що основа пізнавальної активності майбутніх фахівців з пожежної безпеки закладається викладачем у ході лекцій і семінарських занять, що включає в себе розвиток почуття задоволення від озброєння новими знаннями, уміннями і навичками організації своєї розумової праці.

Для активізації науково-дослідницької роботи майбутніх фрахівців з пожежної безпеки необхідним є:

- поглиблення теоретичних знань і практичних умінь відповідно до змісту навчальної дисципліни;

- навчання методології раціонального та ефективного здобування й використання знань;

- активізація участі курсантів та студентів у різних формах як аудиторної, так і позааудиторної роботи. Тому протягом усього періоду навчання необхідно системно й цілеспрямовано залучати курсантів до виконання наукової роботи, створювати проблемі групи з урахуванням наукових інтересів, здібностей, можливостей і досвіду наукової роботи курсантів; забезпечити науково-дослідну базу;

- створення ситуацій успіху при впровадженні в практику наукових результатів;

- заохочення самостійності курсантів та студентів при вирішенні наукових проблем;

- надання можливості публікації результатів досліджень у наукових журналах та збірниках. 
Аналіз наукових розвідок 3 окресленої проблеми $[1 ; 3 ; 4 ; 5 ; 6]$ дозволив виокремити такі визначені принципи підготовки майбутніх фахівців з пожежної безпеки ЗВО ДСНС України до науководослідницької діяльності: системності, безперервності, комплексності, інтегративності, науковості, інноваційності, прогностичності.

Висновки. Науково-дослідницька робота майбутніх фрахівців 3 пожежної безпеки ЗВО ДСНС України розглядається на основі особливостей і перспектив розвитку вищої освіти на засадах компетентнісного підходу, спрямована на вироблення нових наукових знань, теоретичну систематизацію об'єктивних знань про сутність профресійної діяльності.

Перспективи подальших наукових розвідок вбачаємо в розробці критеріїв, рівнів та показників оцінки якості науково-дослідних робіт.

\section{Література}

1. Анищенко В. А. Комплексная система научно-исследовательской работы студентов - основа подготовки конкурентоспособного специалиста. Научно-практическая конференция "Инновационные процессы в системе научно-исследовательской работы студентов» (21-23 фревраля 2006 е.). Оренбург : ИПК ГОУ ОГУ, 2006. С. 30-33.

2. Біда О. А., Савченко О. П. Організація самостійної роботи студентів в умовах кредитно-модульної системи навчання. URL : http://www.nbuv.gov.ua/portal/Soc Gum/Vpm/2009 6/bida.pdf.

3. Драч І. І. Управління формуванням професійної компетентності магістрів педагогіки вищої школи і теоретико-методичні засади : монографія. Київ : «Дорадо-Друк», 2013. 456 с.

4. Кузьмінський А. І. Педагогіка вищої школи : [навч. посібн.]. Київ : Знання, 2005. 486 c.

5. Ротар В. Б. Професійна компетентність майбутніх спеціалістів: теоретичний аспект. Імідж сучасного педагога. 2014. № 6 (145). С. 22-23.

6. Сисоєва С. О., Кристопчук Т. Є. Методологія науково-педагогічних досліджень: підручник. Рівне : Волинські обереги, 2013. 360 с.

\section{References}

1. Anischenko V. A. (2006). Kompleksnaya sistema nauchno-issledovatel'skoy raboty studentov - osnova podgotovki konkurentosposobnogo spetsialista [A comprehensive system of research work of students - the basis of preparation of the competitive expert]. Nauchno-prakticheskaya konferentsiya "Innovatsionnyye protsessy $v$ sisteme nauchno-issledovatel'skoy raboty studentov», 21-23 fevralya 2006 g. Orenburg, 30-33 [in Russian].

2. Bida O. A., Savchenko O. P. (2009). Orhanizatsiia samostiinoi roboty studentiv $\vee$ umovakh kredytno-modulnoi systemy navchannia [Organization of independent work of students in a credit-module system] URL : http://www.nbuv.gov.ua/portal/Soc Gum/Vpm/2009 6/bida.pdf. [in Ukrainian].

3. Drach I. I. (2013). Upravlinnia formuvanniam profesiinoi kompetentnosti mahistriv pedahohiky vyshchoi shkoly i teoretyko-metodychni zasady [Management of formation of professional competence Masters pedagogy of higher education and theoretical and methodological foundations] : monohrafiia. Kyiv : «Dorado-Druk», 2013. $456 \mathrm{~s}$. [in Ukrainian].

4. Kuzminskyi A. I. (2005) Pedahohika vyshchoi shkoly [Pedagogy of high 
school] : [navch. posibn.] Kyiv : Znannia, 2005. 486 s. [in Ukrainian].

5. Rotar V. B. (2014) Profesiina kompetentnist maibutnikh spetsialistiv: teoretychnyi aspekt [Professional competence of future specialists: a theoretical aspect]. Imidzh suchasnoho pedahoha, 2014, № 6 (145), S. 22-23. [in Ukrainian].

6. Sysoieva S. O., Krystopchuk T. Ye. (2013) Metodolohiia naukovopedahohichnykh doslidzhen : pidruchnyk [Methodology of scientific and educational research: Textbook]. Rivne: Volynski oberehy, 2013. 360 s. [in Ukrainian].

\section{АНОТАЦІЯ}

У статті доведено особливу важливість для фахівця з пожежної безпеки певних якостей особистості, зокрема готовності до самоосвіти та креативності. Обгрунтовано, що науково-дослідницькі роботи набувають все більшого значення та перетворюються на одну з основних складових підготовки майбутнього фрахівця з пожежної безпеки в умовах навчання у закладі вищої освіти. Проаналізовано роль науково-дослідницької роботи майбутніх фрахівців з пожежної безпеки в процесі їх професійної підготовки.

Обгрунтовано аргументовану наукову позицію щодо необхідності раціонального поєднання традиційних та інноваційних форм і методів як аудиторної, так і позааудиторної діяльності; рівень складності цілей дослідження; дотримання співвідношення між аудиторною та позааудиторною роботою; забезпечення індивідуального та диференційованого підходів; узгодження інтересів і можливостей здобувача з вимогами навчального плану або цілями та завданнями науково-дослідної роботи; забезпечення достатньої кількості довідкової та методичної літератури, керівництво виконанням окремих завдань; використання цифрових бібліотек (навчання за допомогою електронного підручника, електронних лекцій, рефрератів, використання електронного навчально-методичного комплексу); контроль за виконанням завдань дослідження.

Визначено принципи підготовки майбутніх фрахівців з пожежної безпеки до науково-дослідницької діяльності: системності, безперервності, комплексності, інтегративності, науковості, інноваційності, прогностичності.

Крізь призму компетентнісного підходу розглянуто науководослідницьку роботу майбутніх фрахівців з пожежної безпеки на основі характеристик та перспектив вищої освіти, яка спрямована на розвиток нових наукових знань, теоретичну систематизацію об'єктивних знань про сутність професії.

Перспективи подальших наукових досліджень полягають у дослідженні розробки критеріїв, рівнів та показників оцінки якості дослідження.

Ключові слова: професійна компетентність, фрахівець з пожежної безпеки, науково-дослідницька діяльність. 